\title{
PENGARUH ASUHAN SAYANG IBU TERHADAP KECEMASAN IBU DALAM MENGHADAPI PROSES PERSALINAN DI BPM CH MALA PALEMBANG
}

\author{
Mia Damayanti ${ }^{1}$, Meta Rosdiana ${ }^{2}$ \\ ${ }^{1,2}$ Program Studi DIII Kebidanan, STIK Siti Khadijah Palembang \\ Email: metarosdiana@stik-sitikhadijah.ac.id
}

\begin{abstract}
Abstrack: Effect of Maternal Affection Toward The Mother Anxiety in Facing The Process of Childbirth at BPM CH Mala Palembang. One of the problems that arises in the process of labor is the emergence of anxiety that causes prolonged labor and lead to complications. Health care providers are required to provide care to the maximum mother effort. This is need to reduce the level of maternal anxiety in the face of labor in the form care of maternal affection. The objective of this study to know the effect of maternal affection toward the anxiety mother in facing the process of childbirth at BPM CH Mala Palembang, 2016. This study was pre-experimental designs with draft one-group pretest-posttest design. Population were all mother giving birth with a sample size 23 respondents taken by accidental sampling technique. The result showed that the value-average anxiety scores before being given the care of maternal affection was 37.22 and value-average anxiety scores given care after maternal affection was 19.87 . Statistical test results using $\mathrm{T}$ test dependent were $\rho$ value $=0.0005$. This means that there was the influence of maternal affection towards the care of maternal anxiety in the face of the delivery process.
\end{abstract}

Keywords: Care of maternal affection, Maternal anxiety

\begin{abstract}
Abstrak: Pengaruh Asuhan Sayang Ibu terhadap Kecemasan Ibu dalam Menghadapi Proses Persalinan di BPM CH Mala Palembang. Salah satu masalah yang timbul dalam proses persalinan adalah munculnya kecemasan yang menyebabkan persalinan lama, dan menyebabkan komplikasi, untuk mengurangi tingkat kecemasan ibu dalam menghadapi persalinan, tenaga kesehatan dituntut agar memberikan perawatan kepada ibu secara maksimum untuk mengurangi tingkat kecemasan ibu dalam menghadapi persalinan yang berupa asuhan sayang ibu. Penelitian ini bertujuan untuk mengetahui pengaruh asuhan sayang ibu terhadap kecemasan ibu dalam menghadapi proses persalinan di BPM CH Mala Palembang tahun 2016. Desain penelitian yang digunakan dalam penelitian ini adalah pre-eksperimental designs dengan rancangan one-group pretest-posttest design. Populasi dalam penelitian ini adalah seluruh ibu bersalin dan besar sampel didapatkan 23 responden yang diambil dengan teknik accidental sampling. Hasil penelitian didapatkan nilai rata-rata skor kecemasan sebelum diberikan asuhan sayang ibu adalah 37,22 dan nilai rata-rata skor kecemasan sesudah diberikan asuhan sayang ibu adalah 19,87 . Hasil uji statistik dengan menggunakan uji $T$ dependen didapatkan nilai $\rho$-value $=0,005$ artinya ada pengaruh asuhan sayang ibu terhadap kecemasan ibu dalam menghadapi proses persalinan.
\end{abstract}

Kata kunci : Asuhan sayang ibu, Kecemasan ibu

Mortalitas dan Morbilitas pada wanita hamil dan bersalin merupakan masalah terbesar dinegara berkembang saat ini. Di negara miskin, ada sekitar 25-50\% kematian wanita subur disebabkan karena hal yang berkaitan dengan kehamilan. Kematian saat melahirkan biasanya menjadi faktor utama mortalitas wanita muda pada masa puncak produktifitasnya (Saifuddin, 2006).

Menurut data World Health Organization (WHO) tahun 2014 angka kematian ibu (AKI) di dunia yaitu 289.000 jiwa. Amerika Serikat yaitu 9300 jiwa, Afrika Utara 179.000 jiwa, dan Asia Tenggara 16.000 jiwa. Angka kematian ibu di negara-negara Asia Tenggara yaitu Indonesia 214 per 100.000 kelahiran hidup, Filipina 170 per 100.000 kelahiran hidup, Vietnam 160 per 100.000 kelahiran hidup, Thailand 44 per 100.000 kelahiran hidup, Brunei 60 per 100.000 kelahiran hidup dan Malaysia 39 per 100.000 kelahiran hidup (WHO, 2014).

Menurut data Survei Demografi Kesehatan Indonesia (SDKI) tahun 2012, angka kematian ibu (AKI) di Indonesia sebesar 359 per 100.000 kelahiran hidup. Angka ini masih cukup jauh dari target yang harus dicapai pada tahun 2015 yaitu sebesar 102 per 100.000 kelahiran hidup (Depkes RI, 2012). 
Secara umum, AKI di Indonesia disebabkan oleh perdarahan (28\%), eklampsia (24\%), infeksi (11\%), partus lama/ macet (9\%), komplikasi puerperium (8\%), abortus (5\%), trauma obstetric (5\%), emboli (5\%), dan lain-lain $(11 \%)$. Pada dasarnya, angka kematian ibu (AKI) juga diakibatkan karena beberapa faktor keterlambatan (tiga terlambat) yaitu terlambat dalam pemeriksaan kehamilan, terlambat dalam memperoleh pelayanan persalinan dari tenaga kesehatan, dan terlambat sampai di fasilitas kesehatan (Kemenkes RI, 2011).

Menurut data Sumatera Selatan angka kematian ibu (AKI) karena melahirkan atau saat persalinan pada tahun 2012 sebanyak 148 per 100.000 kelahiran hidup, pada tahun 2013 sebanyak 146 per 100.000 kelahiran hidup, dan pada tahun 2014 AKI meningkat sebanyak 155 per 100.000 kelahiran hidup. (Dinas Kesehatan Provinsi Sumatera Selatan, 2014).

Menurut data Kota Palembang, jumlah kematian ibu tahun 2012 berdasarkan laporan sebanyak 13 orang dari 29.451 kelahiran hidup, pada tahun 2013 AKI sebanyak 13 orang dari 29.911 kelahiran hidup, dan pada tahun 2014 AKI sebanyak 12 orang dari 29.235 kelahiran hidup (Profil Kesehatan Kota Palembang, 2014).

Salah satu upaya pencegahan kematian ibu adalah melakukan asuhan sayang ibu dimana asuhan sayang ibu atau safe motherhood adalah program yang direncanakan pemerintah untuk mengurangi tingginya angka kematian dan kesakitan para ibu yang diakibatkan oleh komplikasi kehamilan dan kelahiran (Purwaningsih, dan Fatmawati, 2010).

Asuhan sayang ibu adalah asuhan dengan prinsip saling menghargai budaya, kepercayaan dan keinginan ibu, salah satu prinsip asuhan sayang ibu adalah dengan mengikutsertakan suami dan keluarga selama persalinan (Hidayat, 2010). Psikologi ibu merupakan salah satu faktor yang mempengaruhi kecemasan ibu dalam menghadapi proses persalinan. Kecemasan atau bahasa inggrisnya anxiety berasal dari bahasa latin angustus yang berarti kaku, dan ango yang berarti mencekik. Kecemasan yang tidak dapat diamati secara langsung dan perasaan tanpa abjek yang spesifik dipicu oleh ketidaktahuan dan didahului oleh pengalaman baru (Stuart, 2007).

Kecemasan pada ibu bersalin kala I bisa berdampak meningkatnya sekresi adrenalin. Salah satu efek adrenalin adalah kontraksi pembuluh darah sehingga suplai oksigen ke janin menurun. Penurunan aliran darah juga menyebabkan melemahnya kontraksi rahim dan berakibat memanjangnya proses persalinan. Selain hanya sekresi adrenalin yang meningkat, menyebabkan peningkatan kadar kortisol serum dan gula darah. Hal ini juga meningkatkan aktifitas saraf simpatik dan meningkatkan sekresi katekolamin yang berlebihan yang akan menimbulkan penurunan aliran darah ke plasenta sehingga suplai oksigen dan penurunan efektifitas kontraksi uterus yang salah satu dampaknya bisa mengakibatkan persalinan lama. Beberapa cara untuk mengatasi kecemasan ibu dalam menghadapi proses persalinan, seperti pendamping saat bersalin, terapi musik, senam hamil, dan asupan gizi.

Menurut Penelitian Putri dan Syakrani (2015), terdapat pengaruh yang signifikan antara asuhan sayang ibu terhadap penurunan tingkat kecemasan ibu dalam menghadapi proses persalinan. Menurut penelitian yang dilakukan oleh Yuliyanti (2014), menunjukkan bahwa penerapan asuhan sayang ibu oleh tenaga kesehatan memiliki pengaruh yang signifikan terhadap tingkat kecemasan ibu primigravida kala I persalinan normal.

Dari hasil studi pendahuluan yang dilakukan di BPM CH Mala Palembang pada tanggal 20-27 Maret 2016, dengan respon 10 responden ibu bersalin terdapat $8(80 \%)$ ibu merasakan cemas, takut, dan khawatir dalam menghadapi proses persalinan sebelum diberikan asuhan sayang ibu.

Berdasarkan uraian di atas, maka penulis tertarik melakukan penelitian lebih lanjut tentang pengaruh asuhan sayang ibu terhadap kecemasan ibu dalam menghadapi proses persalinan di BPM CH Mala Palembang Tahun 2016.

\section{METODE PENELITIAN}

Penelitian ini menggunakan desain preeksperimental designs dengan rancangan OneGroup Pretest-Posttest Design. Populasi adalah seluruh ibu bersalin yang ada di BPM CH Mala Palembang tahun 2016 dengan data 101 pasien yang melakukan persalinan pada bulan JanuariMaret 2016. Besar sampel dalam penelitian ini adalah 23 ibu bersalin yang diambil dengan menggunakan teknik accidental sampling.

Instrumen atau alat untuk data yang digunakan dalam penelitian ini adalah lembar kuesioner dengan menggunaka skala HARS. Uji Statistik yang digunakan adalah Uji T Dependen. 
HASIL

\section{A. ANALISIS UNIVARIAT}

Tabel 1. Rata-Rata Kecemasan Responden Sebelum Diberikan Asuhan Sayang Ibu

\begin{tabular}{lccccc}
\hline $\begin{array}{c}\text { Kecema- } \\
\text { san Ibu }\end{array}$ & $\mathbf{n}$ & Mean & $\begin{array}{c}\text { Stan- } \\
\text { dar } \\
\text { Devi- } \\
\text { asi }\end{array}$ & $\begin{array}{c}\text { Min } \\
\text { Max }\end{array}$ & $\mathbf{9 5 \%} \mathbf{C I}$ \\
\hline $\begin{array}{l}\text { Sebelum } \\
\text { diberikan }\end{array}$ & 23 & 37,22 & 8,893 & $\begin{array}{c}23- \\
50\end{array}$ & $\begin{array}{c}33,37- \\
41,06\end{array}$ \\
\hline
\end{tabular}

Dari tabel 1 dapat dilihat bahwa rata-rata skor kecemasan sebelum diberikan asuhan sayang ibu adalah 37,22 dengan (95\% CI: 33,3741,06), standar deviasi 8,893. Skor terkecil adalah 23 dan skor terbesar adalah 50. Dari hasil estimasi dapat disimpulkan bahwa $95 \%$ diyakini bahwa rata-rata skor kecemasan responden sebelum diberikan asuhan sayang ibu adalah $33,37-41,06$

Tabel 2. Rata-Rata Kecemasan Responden Sesudah Diberikan Asuhan Sayang Ibu

\begin{tabular}{|c|c|c|c|c|c|}
\hline $\begin{array}{c}\text { Kecema- } \\
\text { san Ibu }\end{array}$ & $\mathrm{n}$ & Mean & $\begin{array}{c}\text { Stan- } \\
\text { dar } \\
\text { Devi-asi }\end{array}$ & $\begin{array}{c}\text { Min } \\
- \\
\text { Max }\end{array}$ & $95 \% \mathrm{CI}$ \\
\hline $\begin{array}{l}\text { Sesudah } \\
\text { diberikan } \\
\text { Asuhan }\end{array}$ & $\begin{array}{l}2 \\
3\end{array}$ & 19,87 & 7,910 & $\begin{array}{c}10- \\
40\end{array}$ & $\begin{array}{c}16,45- \\
23,29\end{array}$ \\
\hline
\end{tabular}

Dari tabel di atas dapat dilihat bahwa ratarata skor kecemasan sesudah diberikan asuhan sayang ibu adalah 19,87 dengan (95\% CI: 16,4523,29), standar deviasi 7,910. Skor terkecil adalah 10 dan skor terbesar adalah 40. Dari hasil estimasi dapat disimpulkan bahwa $95 \%$ diyakini bahwa rata-rata skor kecemasan responden sesudah diberikan asuhan sayang ibu adalah $16,45-23,29$

\section{B. ANALISIS BIVARIAT}

Tabel 3. Pengaruh Asuhan Sayang Ibu Terhadap Kecemasan Ibu dalam Menghadapi Proses Persalinan

\begin{tabular}{lccccc}
\hline \multicolumn{1}{|c}{$\begin{array}{l}\text { Kecemasan } \\
\text { Ibu }\end{array}$} & n & Mean & $\begin{array}{c}\text { Standar } \\
\text { Deviasi }\end{array}$ & $\begin{array}{c}\mathbf{9 5 \%} \\
\text { CI }\end{array}$ & $\begin{array}{l}\text { p } \\
\text { value }\end{array}$ \\
\hline $\begin{array}{l}\text { Sebelum } \\
\text { pemberian }\end{array}$ & & & & & 0,005 \\
$\begin{array}{l}\text { asuhan sayang } \\
\text { ibu - sesudah } \\
\text { diberikan }\end{array}$ & 23 & 17,348 & 7,625 & - & \\
$\begin{array}{l}\text { asuhan sayang } \\
\text { ibu }\end{array}$ & & & 20,645 & \\
\hline
\end{tabular}

Dari tabel terlihat bahwa hasil uji statistik parametrik (Uji T-test berpasangan/ uji paired sample t-test) di dapatkan nilai $\rho$-value $=0,005$ karena probabilitas tersebut lebih kecil dari taraf nyata $\alpha=0,05$ maka dapat disimpulkan terlihat ada pengaruh yang signifikan rata-rata skor kecemasan sebelum dan sesudah diberikan asuhan sayang ibu dalam menghadapi proses persalinan.

\section{PEMBAHASAN}

1. Kecemasan Ibu Sebelum diberikan Asuhan Sayang Ibu dalam Menghadapi Proses Persalinan

Hasil analisis didapatkan rata-rata skor kecemasan responden sebelum diberikan asuhan sayang ibu adalah 37,22 dengan (95\% CI: 33,3741,06), standar deviasi 8,893. Skor terkecil adalah 23 dan skor terbesar adalah 50. Dari hasil estimasi dapat disimpulkan bahwa 95\% diyakini bahwa rata-rata skor kecemasan responden sebelum diberikan asuhan sayang ibu adalah $33,37-41,06$.

Hasil penelitian ini sejalan dengan teori Murwani (2008) bahwa Cemas adalah perasaan takut yang tidak jelas dan tidak didukung oleh situasi. Ketika merasa cemas, individu merasa tidak nyaman atau takut atau mungkin memiliki firasat akan ditimpa malapetaka padahal ia tidak mengerti mengapa emosi yang mengancam tersebut terjadi.

Hasil penelitian ini juga sejalan dengan hasil penelitian dari Putri dan Syakrani (2015) yang mengatakan bahwa dari hasil analisa univariat didapatkan ibu yang mengalami cemas berat sebanyak 1 orang $(6,6 \%)$, cemas sedang sebanyak 10 orang $(66,6 \%)$, cemas ringan sebanyak 4 orang $(26,6)$ dan yang tidak mengalami cemas 0 orang $(0 \%)$.

Berdasarkan hasil penelitian, teori dan penelitian terkait bahwa setiap ibu yang akan menghadapi proses persalinan mengalami kecemasan karena ibu takut dan cemas akan terjadinya hal-hal yang tidak di inginkan seperti: takut tidak bisa melewati proses persalinan, trauma karena kejadian masa lampau (kejadian sebelumnya), tidak di dampingi keluarga/ suami sehingga tidak merasa diberi dukungan secara fisik dan emosional.

\section{Kecemasan Ibu Sesudah diberikan Asuhan Sayang Ibu dalam Menghadapi Proses Persalinan}

Hasil analisis didapatkan rata-rata skor kecemasan responden sesudah diberikan asuhan 
sayang ibu adalah 19,87 dengan (95\% CI: 16,4523,29), standar deviasi 7,910. Skor terkecil adalah 10 dan skor terbesar adalah 40. Dari hasil estimasi dapat disimpulkan bahwa $95 \%$ diyakini bahwa rata-rata skor kecemasan responden sesudah diberikan asuhan sayang ibu adalah $16,45-23,29$

Hasil penelitian ini sejalan dengan teori Murwani (2008) bahwa Cemas adalah perasaan takut yang tidak jelas dan tidak didukung oleh situasi. Ketika merasa cemas, individu merasa tidak nyaman atau takut atau mungkin memiliki firasat akan ditimpa malapetaka padahal ia tidak mengerti mengapa emosi yang mengancam tersebut terjadi.

Hasil penelitian ini juga sama dengan penelitian yang dilakukan oleh Putri dan Syakrani (2015) yang mengatakan bahwa dari hasil analisa univariat didapatkan ibu yang mengalami cemas berat sebanyak 0 orang $(0 \%)$, cemas sedang sebanyak 6 orang $(39,9 \%)$, cemas ringan sebanyak 9 orang $(59,9 \%)$.

Berdasarkan hasil penelitian, teori dan penelitian terkait bahwa sesudah diberikan asuhan sayang ibu menyebabkan penurunan skala kecemasan yang signifikan dikarenakan ibu merasa lebih nyaman, senang dan merasa bahwa dirinya dihargai dan diberi dukungan oleh keluarga/ suami.

\section{Pengaruh Asuhan Sayang Ibu terhadap Kecemasan Ibu dalam Menghadapi Proses Persalinan}

Berdasarkan uji hasil uji statistik parametrik yaitu Uji T-test berpasangan/ uji paired sample t-test, dapat disimpulkan ada pengaruh yang signifikan antara kecemasan sebelum dan sesudah diberikan asuhan sayang ibu $(\rho$-value $=0,005)$.

Hasil Penelitian ini sejalan dengan teori Sujiyatini (2011) bahwa asuhan sayang ibu adalah asuhan yang menghargai budaya, kepercayaan, dan keinginan sang ibu. Salah satu prinsip dasar asuhan sayang ibu adalah dengan mengikutsertakan suami dan keluarga selama proses persalinan dan kelahiran bayi.

Menurut Kartono (2006) yang mengatakan bahwa cara mengatasi masalah psikologi pada ibu bersalin adalah kegiatan komunikasi dan konseling yang berupa pemberian asuhan sayang ibu dengan memberikan dukungan emosional serta dukungan suami/ keluarga.

Hasil penelitian ini sejalan dengan hasil penelitian dari Putri dan Syakrani (2015) yang mengatakan bahwa didapatkan dari hasil analisa bivariat diperoleh $\rho$-value $0,000(\rho<0,05)$ yang menunjukkan Ha diterima yang berarti terdapat pengaruh yang signifikan sebelum dan sesudah diberikan asuhan sayang ibu antara kelompok kontrol dan kelompok intervensi.

Berdasarkan hasil penelitian, teori, dan penelitian terkait bahwa asuhan sayang ibu ini adalah salah satu metode atau cara yang bisa membuat penurunan kecemasan ibu dalam menghadapi proses persalinan, dimana dalam memberikan asuhan sayang ibu selain oleh tenaga kesehatan, keluarga dan dukungan suami turut berperan penting dalam menurunkan kecemasan ibu dalam menghadapi proses persalinan. Walaupun dilaksanakan asuhan sayang ibu, tetapi dukungan emosional dan dukungan suami/keluarga yang diberikan tidak maksimal juga tidak akan menghasilkan hasil yang baik. Asuhan sayang ibu dapat diberikan dengan cara memberi dukungan emosional, mengatur posisi ibu, pemberian cairan nutrisi dan hidrasi, serta pencegahan infeksi, sehingga ibu akan merasa nyaman, senang, dan merasa bahwa dirinya dihargai.

\section{SIMPULAN}

Berdasarkan tujuan penelitian dan pembahasan yang telah disajikan, maka dapat disimpulkan sebagai berikut :

1. Rata-rata skor kecemasan responden sebelum diberikan asuhan sayang ibu dalam menghadapi proses persalinan adalah 37,22 dengan standar deviasi 8,893.

2. Rata-rata skor kecemasan responden sesudah diberikan asuhan sayang ibu dalam menghadapi proses persalinan adalah 19,87 dengan standar deviasi 7,910.

3. Ada pengaruh asuhan sayang ibu terhadap kecemasan ibu dalam menghadapi proses persalinan di BPM CH Mala Palembang Tahun 2016 dengan $\rho$-value $=0,005$.

\section{SARAN}

Hasil penelitian ini diharapkan dapat dijadikan acuan bagi tenaga kesehatan agar meningkatkan penerapan asuhan sayang ibu secara maksimal untuk mengurangi kecemasan ibu dalam menghadapi proses persalinan dengan memberikan arahan kepada suami untuk menemani istri pada saat proses persalinan, bidan juga sebaiknya memberikan penyuluhan kepada suami mengenai persiapan persalinan baik dari perlengkapan bayi, ibu maupun administrasi yang diperlukan agar sewaktu-waktu dapat siap 
apabila sudah ada tanda-tanda persalinan sehingga ibu tidak merasa cemas dan khawatir.

\section{DAFTAR PUSTAKA}

BPM CH Mala Palembang. 2015. Jumlah Ibu Bersalin. Palembang

Depkes, RI. 2012. Angka Kematian Ibu. Jakarta.

Dinas Kesehatan Provinsi Sumatera Selatan. 2014. Angka Kematian Ibu Provinsi SumSel. http://dinkes.sumselprov.go.id/downlot.ph p (Diunduh pada tanggal 23 Maret 2016).

Hidayat, Asri. 2010. Asuhan Kebidanan Persalinan. Yogyakarta: Mulia Medika.

Kartono. 2006. Psikologi Wanita. Bandung: Mandar Maju.

Kemenkes, RI. 2011. Angka Kematian Ibu di Indonesia. Jakarta.

Murwani, Setyowati. 2008. Asuhan Keperawatan Keluarga. Jogjakarta: Mitra Cendika.

Profil Kesehatan Kota Palembang. 2014. Dinas Kota

Palembang. http://dinkes.palembang.go.id/tampung/do kumen/dokumen-87-120.pdf
Purwaningsih, W., \& Fatmawati, S. 2010. Asuhan Keperawatan Maternitas. Yogyakarta: Nuha Medika.

Putri, D., Syakrani, F. 2015. Pengaruh Asuhan Sayang Ibu Terhadap Tingkat Kecemasan Ibu Dalam Menghadapi Proses Persalinan. Jurnal Kebidanan Stikes Yarsi Sumbar.

Stuart, G.W. 2007. Buku Saku Keperawatan Jiwa. Edisi 5. Jakarta: EGC.

Sugiyono. 2014. Metode Penelitian Kuantitatif, Kualitatif, dan $R \& D$. Bandung: Alfabeta.

Sujiyatini. 2011. Asuhan Kebidanan II (Persalinan). Yogyakarta: Rohima Press.

Saifuddin, B.A. 2006. Buku Acuan Nasional Pelayanan Kesehatan Maternal dan Neonatal. Jakarta: Yayasan Bina Pustaka Sarwono Prawirohardjo.

WHO. 2014. World Health Report 2013. http://www.who.int/whr/2013/annex/annex es3-4_en.pdf (Diakses pada tangal 23 Maret 2016). 